\title{
A Tale of Two Markets: How Lower-end Borrowers Are Punished for Bank Regulatory Failures in Nigeria
}

\section{P. I. Omede ${ }^{1}$}

Received: 24 October 2018 / Accepted: 7 November 2019 /Published online: 23 December 2019

(C) The Author(s) 2019

\begin{abstract}
In 2009, the Nigerian banking system witnessed a financial crisis caused by elite borrowers in the financial market. Regulatory response to the Nigerian crisis closely mirrored the international response with increased capital and liquidity thresholds for commercial banks. While the rise of consumer protection on the agenda of prudential supervisors internationally was logical in that consumer debt was the main cause of the global recession, the Nigerian banking reforms of 2009 disproportionately affected access by poorer consumers, who ironically had little to do with the underlying causes of the crisis. As lending criteria become more stringent, poorer consumers of credit products are pushed into informal markets because of liquidity-induced credit rationing. Overall, consumer protection is compromised because stronger consumer protection rules for the formal sector benefits borrowers from formal institutions who constitute the minority of borrowers in all markets. While the passage of regulation establishing credit bureaux and the National Collateral Registry will, in theory, ease access to credit especially by lower-end borrowers, the vast size of the informal market continues to compound the information asymmetry problem, fiscal policies to tackle structural economic issues such as unemployment and illiteracy remain to be initiated, and bank regulators continue to pander to elite customers with policy responses that endorse too big to fail but deems lower-end consumers too irrelevant to save. The essay concluded that addressing the wide disparity in access to credit between the rich and poor through property rights reforms to capture the capital of the informal class, promoting regulation to check loan concentration, and stimulating competition by allowing Telecommunication Companies (TELCOs) and fintech companies to carry on lending activities because of their superior knowledge of lower-end markets will facilitate greater access. The risk of systemic failure deriving from consumer credit in Nigeria is insignificant compared to the consumer vulnerabilities resulting from the exposure of consumers to unregulated products in the informal market.
\end{abstract}

Keywords Consumer credit · Financial regulation · Emerging markets · Informal markets · Systemic risk

\section{P. I. Omede}

pio4@kent.ac.uk

1 Kent Law School, University of Kent, Canterbury, UK 
The banking system in Nigeria witnessed a liquidity crisis in 2009 , partly caused by the global recession, but fundamentally, the outcome of unrelated home-grown issues (Kuye et al. 2013, p. 174). The Nigeria Stock Exchange lost about $70 \%$ of its value in 2007-2008, and the Central Bank of Nigeria had to intervene with liquidity injection of up to USD 31.1 billion (Central Bank of Nigeria 2010, p. 58).

Since the global recession (2007-2009), the link between consumer debt and financial stability has received considerable attention (US Department of the Treasury 2009, pp. 55-61). The main causes of the recession were subprime mortgages, the mass selling of securities backed by subprime mortgages to firms outside the traditional banking system, little understanding of these complex products by regulators, and the transboundary marketing of these products (Bernanke et al. 2019, p. 11). The consequences for households such as foreclosures and failed investments focused attention on excessive household leverage and its implications for the financial system. Before the recession, consumer debt was considered a consumer protection concern but not as a major systemic risk factor. Following directly from the lessons of the recession, regulators across the world have adopted a new approach to regulation that locates consumer debt within the purview of prudential regulation (European Commission 2012, p. 94; HM Treasury 2009, p. 103). Consumer credit and debt, for the purposes of this paper, embraces "both money that is lent and borrowed as money, without being specifically tied to the purchase of any particular goods and services, and also any part of the purchase price of specific goods and services that is not paid on the spot but deferred for later settlement" (Committee on Consumer Credit Law 1971, p. 13). Accordingly, the analyses will focus on the protection of users of consumer credit (consumer borrowers) rather than consumers of banking or financial services generally. Specifically, it focuses on borrowers at the bottom of the market pyramid described here variously as "lower-end," "low-income," "poor," or "informal sector" borrowers. This includes the people employed in the informal economy, e.g., petty traders, farmers, junior civil servants, and the $95 \%$ of Nigerian adults who are unable to access credit from the formal markets according to the Central Bank of Nigeria.

Regulatory response to the Nigerian crisis has closely mirrored the international response with increased capital and liquidity thresholds for commercial banks. The intervention of the Central Bank of Nigeria was predicated on the need to avoid a systemic collapse and to ensure the protection of financial consumers. While the renewed focus on consumer protection since the recession is a positive step, some of the policies introduced to achieve this by prudential supervisors limit financial access for the more vulnerable credit consumers especially in emerging market economies where credit uptake amongst Micro, Small, and Medium Scale Enterprises (MSMEs) and individual consumers is remarkably low.

This essay will argue that the Nigerian banking reforms of 2009 disproportionately affected access by poorer consumers, who ironically had little to do with the underlying causes of the crisis. The integration of consumer protection into prudential oversight at the international level is logical in that consumer debt was the main cause of the global recession. It, however, speaks to the dissonance between international approaches to financial regulation and the realities of developing and emerging economies. Rather than strengthen consumer protection, tighter prudential requirements have had the effect of excluding lower-end borrowers from the formal market, and therefore affording protection for the elite few who remain in the formal market, and ironically responsible for the Nigerian bank crisis of 2009.

The first part provides a brief historical account of consumer lending in Nigeria and an overview of the banking crisis of 2009 and the regulatory reforms that were implemented. The second part will argue that the reforms implemented made it harder for lower-end consumers to 
access formal credit products, forcing them to subscribe to unregulated credit products. The third part will attempt a cost-benefit analysis of the reforms and argues that while the passage of regulation establishing credit bureaux and the National Collateral Registry will, in theory, ease access to credit especially by lower-end borrowers, the vast size of the informal market continues to compound the information asymmetry problem, fiscal policies to tackle structural economic issues such as unemployment and illiteracy remain to be initiated, and bank regulators continue to pander to elite customers with policy responses that endorse too big to fail but deems lower-end consumers too irrelevant to save. The essay concludes that the risk of systemic failure deriving from consumer credit in Nigeria is insignificant compared to the consumer vulnerabilities resulting from the exposure of consumers to unregulated products in the informal market.

\section{A Brief History of Consumer Lending in Nigeria}

Consumer policy in developing countries is inextricably linked to global systems. In Nigeria, colonial legacies such as the inherited legal system and banking model continue to operate with mixed outcomes for consumers, while policies of high-income countries on trade and investment, security, and intellectual property rights continue to influence domestic policy and impact significantly on economic growth and living standards in developing countries. For instance, many developing countries show an obsession with improving scores on the World Bank's Ease of Doing Business Index with a view to attracting foreign investment. While this is not necessarily a bad thing to do, there has been scepticism about its relevance to real improvement in national business environments (McCormack 2018).

Immediately after gaining independence from Britain in 1960, the Nigerian government adopted an interventionist (state-centric) approach to stimulate economic development via measures including free education and healthcare programmes, interest rate controls, and direct allocation of credit to priority sectors and rural areas where private financial institutions would not ordinarily direct resources (Woods 2006, p. 141; World Bank 1989, pp. 1-3). These policies benefitted most citizens, regardless of social and economic class. Credit offers opportunities for households to accumulate wealth and expand job opportunities (Bar-Gill and Warren 2008, p. 5). People borrow to smooth temporarily unstable income, and particularly in times of wider economic downturn, credit is beneficial even when it is expensive (Bertrand et al. 2010, p. 302; Guerrieri and Lorenzoni 2011, pp. 1429-1430; Morse 2011, pp. 28-29). Families in distress can count on credit as a critical safety net when they face economic shocks such as a job loss, failed marriages, or ill heath, with the promise to pay back in the future when things get better. Public policy seems to accept this welfare-enhancing quality of consumer credit gradually. The European Union's (EU) commitment to a market-driven approach to financial inclusion is predicated on the vision of cheap credit as a means of achieving financial and social inclusion (Comparato 2016, pp. 9-10). The vision of credit as a social safety net was also pursued in postapartheid South Africa, while the Community Reinvestment Act 1977 in the United States of America (USA) also reflects this approach in some ways (James 2015, p. 15).

State welfare programmes in Nigeria between 1960 and 1983, however, were in part made possible by the oil booms of the 1970s and heavy borrowing from international institutions such as the World Bank and the International Monetary Fund (IMF). This borrowing and the subsequent dependence on foreign technical support made it possible for these external institutions to gain a foothold on the domestic policy landscape of Nigeria (Woods 2006, p. 
141). This period (1983-1989) marked the rebirth of monetarism in Nigeria through the Structural Adjustment Programme (SAP) (Sofola 1988, pp. 202-203). The World Bank's solutions to the economic problem of Nigeria consisted mainly in privatization, liberalization, and formalization (World Bank 1989, p. 3). Privatization and liberalization, according to the institutions, would make for better competition, and allowing market forces to thrive by removing controls, "directed credit" programmes and subsidies would serve the economy better. Thus, SAP emphasized credit availability but ignored the question "to whom?"

While the international institutions were right to point out the implementation failures of the state-centric model riddled by official corruption, rapid inflation, and other macroeconomic imbalances, monetarism and financial liberalization ignore the social and economic well-being objectives that the previous model sought to achieve by promoting access to affordable finance. As far as SAP went, the individual welfare of consumers was an afterthought. This critique of SAP continues to be relevant in the present day because some of its negative consequences for consumers in affected countries continue to be seen (Konadu-Agyemang 2001, p. 456). Although this paper is not primarily a critique of SAP, a brief analysis of SAP provides the necessary context for understanding the research question. By devaluing the Naira and implementing government austerity introducing tuition and surcharges for health services, access to basic services like education and healthcare declined significantly, and the overall quality of services was undermined. Thus, SAP increased the demand for consumer credit and decreased the opportunity to access safe credit products in the newly deregulated market. The resulting adverse conditions grossly diminished individual and collective capacities to save, invest, and fund consumption without borrowing. Beyond these immediate consequences, Nigeria is stuck on the policy path charted by SAP despite the World Bank and OECD countries embracing a more regulatory approach to credit regulation generally. For instance, the World Bank's Good Practices for Financial Consumer Protection 2017 promotes ex ante approaches to consumer protection and embraces behavioural science in regulatory policy, signalling a willingness to depart from neo-classical economics assumption of consumers as rational agents where the empirical evidence proves otherwise (World Bank 2017).

The persistence of regulatory policy orthodoxy in Nigeria (i.e., in contrast to the shifting regulatory approach in international financial institutions and regulators in advanced countries) is not surprising since developing countries are less likely to experience the convergence of the strong institutions, political ideology, and technocratic tools necessary for switching policy paradigms where the likely principal beneficiaries are non-elite groups (Capoccia 2015, p. 150; Hall 1993, p. 275). It is against this background that this paper was conceived.

\section{The Nigerian Banking Crisis 2009}

Since 2001, Nigeria adopted the Universal Banking (UB) model, which permitted banks to expand into non-traditional bank businesses (Sanusi 2012, p. 116). In 2005, the Central Bank of Nigeria (CBN) raised the capital base for banks in Nigeria from N2 billion [USD 13424 200] to a minimum of N25 billion [USD 167803 000] (Apati 2012, p. 52; Sanusi 2010, p. 2). Consequently, the 89 licensed banks, through mergers and acquisitions, coalesced into 25 and later 24. In spite of the consolidation, the banking system in Nigeria witnessed a liquidity crisis in 2009, partly caused by the global recession, but a majority of the underlying concerns were home grown (Kuye et al. 2013, p. 174). According to the Central Bank of Nigeria (2010, p. 58), the factors that led to this crisis include the following: 
1. Large and sudden capital inflows that created macroeconomic instability: Capital inflows from high crude oil sale created a procyclical spending habit in public expenditure while the excess liquidity also created by the influx of foreign investment encouraged banks into lending to non-priority sectors such as the Nigeria Stock Exchange (NSE), mostly in the form of margin loans and proprietary trading, disguised as loans (Central Bank of Nigeria 2010 , p. 58). Nigerian banks were highly exposed to the oil and gas sector, which rode on high oil prices. With the global recession forcing down crude oil prices, the bubble bust with an adverse effect on the oil and gas sector, the capital market, and the banks.

2. Critical gaps in the regulatory framework and regulation: Reports of fraud in several banks were left untreated in spite of being aware of the same. The Financial Services Regulation Coordinating Committee, which is vested with that mandate, did not meet for two years.

3. Weaknesses in the business environment: Poor banking practices were rampant. From poor infrastructure to the absence of credible rating agencies which made an assessment of creditworthiness difficult. More importantly, the legal process was cumbersome, making the recovery of debt and bank foreclosure on borrowers difficult. This facilitated the abuse of bank credits by borrowers (Central Bank of Nigeria 2010, p. 58).

Additional issues include corporate governance failures, insufficient disclosure and transparency on the exact financial position of banks, double standards in supervision and enforcement by regulators, and poor governance and management methods at the CBN (Central Bank of Nigeria 2010, p. 58).

\section{Government Response to the Crisis}

Following a stress test carried out by the CBN in August 2009, eight banks were found to be distressed (Central Bank of Nigeria 2010, p. 58). The banks had accumulated USD 11 billion non-performing loans (NPL). These banks were directed to seek new investments before August 2011 or have their licences revoked.

In addition to the liquidity support of USD 4 billion:

i. The CBN reviewed the UB Model and directed banks to focus on core banking business and banks working as private equity, and venture capital funds were required to divest accordingly.

ii. Bank chief executives were removed, and tenure limits for chief executive officers were restricted to 10 years. Sixteen senior bank officials were prosecuted for charges that included fraud, lending to non-existent companies, lending to companies owned by them, and conspiring with stockbrokers to boost share prices.

iii. The CBN imposed an additional $1 \%$ of capital on the systemically important banks (SIB) as higher loss absorbency (HLA) charge, in addition to the prescribed minimum capital adequacy ratio (CAR) of $15 \%$, taking the overall CAR to $16 \%$ and a liquidity ratio of 35\% (Central Bank of Nigeria 2010, p. 58; This Day Live 2015).

iv. Establishment of the Asset Management Corporation of Nigeria (AMCON) with the mandate to acquire the NPLs of Eligible Financial Institutions (EFIs); to inject capital into the intervened banks so as to stave off insolvency; and to manage acquired assets in a profitable manner that avoids losses to the taxpayers (Chike-Obi 2014; Wallace 2015). It 
used bonds to bail out ten lenders and buy more than 12000 loans from industries including aviation, gasoline, marketing, and manufacturing for about 1.8 trillion Naira (USD 9 billion) (Sanusi 2012, p. 117).

v. The Federal Government through the Central Bank sought to stimulate the market by approving bailout funds to state governments which were facing a solvency crisis of their own. This was necessitated by the reality of the country's political economy. Nigeria operates a federal political structure but a unitary fiscal system such that state governments are financially dependent on the central government for revenue to pay wages and run government.

Although AMCON claims to have recovered 57\% of the NPLs (Wallace 2015), it has also recorded a total loss of USD 20.8 billion between 2010 and 2012, and USD 1.2 billion in 2016 (AMCON 2018). The rationale for intervention is that the loss to the public treasury is less than the systemic failure that could have resulted had the CBN and AMCON not intervened as they did. However, the point of detailing the losses in this essay is to emphasize how a few elite borrowers and irresponsible bank executives cost the tax payer fortunes, and how poorer borrowers bear the burden of resulting regulation disproportionately. The following sections explain this point in greater detail.

\section{Macroprudential Policy, Consumer Protection, and Access to Finance in Nigeria}

The Basel Committee on Banking Supervision initiated a set of reforms to strengthen the resilience of financial institutions, particularly, Global Systemically Important Banks (GSIBs). GSIBs were required to hold more capital and of higher quality as a ratio of their total lending. More so, they were required to hold more liquid assets and cash to check bank runs (Bank for International Settlements 2017, p. 1). The principal objective of the requirements was to ensure that banks are "sufficiently resilient to withstand losses in times of stress" (Bank for International Settlements 2017, p. 1).

The reforms came at a cost to economic growth and consumer welfare in the short term even though projected benefits were expected to manifest over the long term. According to the report of the Basel Committee on Banking Supervision and Financial Stability Board, the estimated cost of the reforms would be an output loss of $0.03 \%$ per annum (Bank for International Settlements 2010, p. 1). The International Institute of Finance (IIF) on the other hand published a less optimistic estimate of a 3.2\% lower level of GDP growth after five years with an output loss of $0.7 \%$ per annum (Institute of International Finance 2011, p. 9). An OECD study estimated an average increase in lending spreads of 50 basis points by 2019 and found that a $1 \%$ increase in bank capital requirement could create an average negative impact of $0.04 \%$ per annum and $0.20 \%$ on the GDP level five years after implementation (Slovik and Cournède 2011, p. 9).

In practice, higher capital and liquidity ratios constrain access to credit, especially by lowerend consumers. This class of borrowers is typically considered to be riskier and usually have to pay more where credit is advanced to them (Ramsay 2012, p. 44). In emerging markets, the adverse impact of increased liquidity and capital requirements on credit flows to small businesses and individual consumers is more prominent as lenders confront persistent liquidity shortages due to shallow capital markets and customers' lack of capacity to leave deposits with 
banks for a long time (Sinha et al. 2011, p. 78). A cursory study of three African financial markets - Ethiopia, Kenya, and Lesotho - found that despite increased competition and greater effort to promote financial inclusion, the weak funding structure (a bank-based financial system) of financial institutions makes it difficult for the lower end of the market to access credit (Gottschalk 2015, p. 5).

The problem of Basel II for Nigeria is not whether the objectives are altruistic or not, or that developing countries, including Nigeria, have to choose between financial inclusion and financial stability. That, of course, is a false choice considering that effective regulation can balance both needs. The critique of interest here is that BASEL II is only one of the prudential policy tools that could be implemented to stabilize the economy, ineffective when applied in isolation, and the tool that hurts lower-end borrowers the most. Obsession with higher liquidity and capital requirement, without adequate regulation to address loan concentration and proprietary trading is ineffective as a prudential tool for Nigeria (and by extension other Sub-Saharan African markets) because of the existing high magnitude of non-performing loans and the extremely volatile financial environment (Kasekende et al. 2011, p. 11; Loayza et al. 2007, p. 347). Nigeria's HLA and CAR, like in many other African countries, was already above BASEL III but that in itself could not prevent the crisis of 2009 (Kasekende et al. 2011, p. 11).

As noted in the earlier section, sudden capital inflows into Nigeria created excess liquidity which encouraged banks into lending to non-priority sectors such as the NSE, mostly in the form of margin loans and proprietary trading, disguised as loans. However, only a handful of individuals benefitted from the heightened appetite for lending by financial institutions within this period, which in turn invested in a narrow set of volatile assets. Thus, loan concentration in a few borrowers and confined to a narrow sector, as is historically the case with African economies (Narain et al. 2003, p. 3), was the primal systemic risk factor, further complicated by weaknesses in the legal system which impede banks' ability to recover loans and foreclose on loan security.

The Central Bank of Nigeria by adopting the reforms highlighted earlier including increasing the HLA and CAR of SIBs to $16 \%$ and raising the liquidity ratio to $35 \%$ was able to avert the risk of systemic failure. The measures taken however were incomplete in that the issue of loan concentration was not addressed, and had unintended but harsh consequences on consumer lending and access to finance. Some $93 \%$ of potential borrowers could not access a loan in 2012, and despite a total of around 42 million adults in employment, Nigeria only has 8.2 million active borrowers, of whom a mere 1.6 million held loans from banks in 2012 (Oxford Business Group 2015). According to the Financial Inclusion Secretariat, Central Bank of Nigeria (CBN), formal sector credit penetration as a ratio of the adult population in Nigeria was below 5.3\% in 2017, while interest rates range from 16.68 to $49 \%$ (Euromonitor International 2018). However, gaps in access to finance in Nigeria are differentiated with higher exclusion levels recorded amongst women, rural dwellers, youth, people living in North East and North-West Nigeria, the disabled and Micro Small and Medium Enterprises (CBN 2018, p. 13).

\section{Why International Rules Are Often Ineffective in Developing Markets}

There exists a mismatch between international policy prescriptions and the regulatory challenges of developing economies. This mismatch has been demonstrated in this essay in the context of post-global recession reforms of credit regulation and banking reforms around capital and liquidity ratios. This is, however, not surprising given that policy makers from emerging markets, especially sub-Saharan African countries, hardly participate in the rule- 
making processes. International consumer policy is overwhelmingly the output of deliberations by the club of rich countries. At the IMF and World Bank where developing countries are guaranteed a seat at the table, votes are allocated according to an unevenly weighted quota, with $41.72 \%$ of the votes held by G7 countries (Woods 2006, pp. 141-155). It achieves its ends often through national courts via the recognition and enforcement of foreign arbitral awards, sanctioning the seizure of assets of poor countries during sovereign defaults, or declining jurisdiction over abuses by MNCs. More controversial, however, is the conduct of international financial regulation through international soft law regulation facilitated by network governance (Muir-Watt 2011, pp. 347-348; Muir-Watt 2015, p. 1). International standard setting bodies such as the Basel Committee on Banking Supervision, Financial Stability Board, International Monetary Fund, and the World Bank consist mostly of unelected experts who make financial rules that even when qualified as voluntary, are enforced in jurisdictions unrepresented in these clubs. The IMF's Financial Sector Assessment Programme (FSAP) considers the observance of standards and codes issued by these bodies as part of its assessment of prudential regulations and supervision even where the country under assessment is not a member of the institution issuing the standard or code (Brummer 2010, p. 384; Onagoruwa 2014, p. 258).

Several arguments have been advanced for the failure to include poorer countries in international regulatory authority. The most prominent is that developing countries cannot make meaningful contributions to the policy formulation process (Santos 2012, p. 551; Shaffer et al. 2015, p. 595). This may well be true, but without participation, developing countries could never build requisite capacity. Another argument is that maintaining a small-size membership is central to the effectiveness of these bodies. There is, however, a large body of empirical findings that contradict this conclusion (Campos and Nugent 1999, p. 439; McCallum and Blais 1987, pp. 1-2; Underhill and Zhang 2006, p. 49). Rather, this framework only succeeds in perpetuating neo-colonialism (Shaffer et al. 2015, pp. 595-597). The point here is neither to argue that soft law is bad nor that OECD members lack the technical expertise to make sound consumer policy. The argument is that developing countries do have issues that go beyond the reach of the agenda of the standard setting bodies and national regulators must make a policy of filling such gaps and also act as counter-hegemons by not simply applying these norms but being able to "resist, block, translate, adapt, and hybridize them, giving rise to localized globalisms" (Shaffer et al. 2015, p. 601). For instance, the implementation of neoliberal policies such as privatization is based on assumptions that existing institutions like the Bureau of Public Enterprises in Nigeria will organize a transparent auction with competitive bidding taking place. However, privatization in the past has become an avenue for public servants to sell government assets to themselves for cheap while siphoning the proceeds of the sale to private accounts.

Similarly, deregulation in the absence of well-established financial infrastructure has fuelled more loan concentration, speculation, and corrupt patronage between bank boards and regulators. Another example is the responsibility that national regulators must bear for resolving tensions between imported legal systems and customary business practices that work for local consumers. In all these examples, national regulators are better placed to make the right policy choices because of their deeper understanding of the domestic challenges. The perceived fairness of the UN Model Tax Treaty to developing countries over the OECD model in the allocation of taxing powers is considered by some as "evidence of the gains of diversity" on rule-making bodies (Anderson 2005, p. 1278; Onagoruwa 2014, p. 258). It is important to make the point that mere inclusion without consequential voting powers is almost as deplorable as absolute exclusion. 
Secondly, if there is one lesson to learn from the aftermath of the global recession, it is that technical infallibility is not a criterion for inclusion in network governance.

In the next section, I will argue that the majority of consumers excluded from accessing credit in formal markets resort to informal markets (and outside prudential oversight) which undermines consumer protection as their vulnerabilities are most likely to be exploited in this sector. I will critically assess the overall consumer credit uptake levels and the risk that poses to financial stability in Nigeria.

\section{Safe Products for the Rich, Unregulated Products for the Poor}

\section{Informal Credit and Consumer Harm}

This Section argues that rather than protect consumers, which is a direct objective of integrating consumer protection into prudential policy post-global recession, regulation in Nigeria has pursued financial stability at the expense of lower-end consumers.

Developing countries typically maintain a dual economy where an informal market co-exists with a formal one, and operators are often able to access services in either or both markets concurrently or at different times (Jain 1999, p. 419; Kochar 1997, p. 339; Yuan and Xu 2015, p. 232). Nigeria's informal sector forms $65 \%$ of gross domestic product, larger than those of Brazil, Ghana, Turkey, Malaysia, and South Africa according to World Bank estimation (International Monetary Fund 2017, p. 50; Sanusi 2010, p. 8). Common obstacles to accessing formal credit by lower-end borrowers in Nigeria include stringent Know-Your-Customer (KYC) requirements necessitated in part by anti-money laundering regulations, lenders' preference for corporate and high-net-worth borrowers, and the prevalence of a relational lending culture in commercial banks which significantly makes social proximity to bank managers salient to the success of loan applications (Apati 2012, pp. 1-15; Kang 2018, p. 695; Odetola 2018; Udry 1990; Woods 2006, pp. 150-155; World Bank 1989, p. 3). For example, Section 20 of the Banks and Other Financial Institutions Act 2004 generally discourages unsecured lending by banks and provides for civil and criminal liabilities for bank officers and corporate liabilities for the bank. This has created a business climate where formal lenders have little appetite for risk-taking. As lower-end borrowers are more likely to apply for unsecured loans and less likely to own collateral, this provision naturally impacts them more harshly (Bertola et al. 2006). These obstacles make it difficult for formal lenders to appraise the credit risk profile of individual borrowers and the likelihood of loan recovery, and therefore, unwilling to lend (CBN 2018, p. 13). Although the Civil Procedure Rules of the various States of the Federation make provision for a fast track rule towards disposing off matters of liquidated money demands which are often filed on the undefended list, shrewd lawyers always figure a way to move such matters to the General Cause list where litigation gets protracted. ${ }^{1}$ With the hardship of debt recovery in Nigeria, lending, especially to the poor, poses a clear moral hazard as the gain derivable from non-repayment outweighs the punishment for default (Zinman 2014).

\footnotetext{
${ }^{1}$ For instance, the Nigerian Supreme Court case of Khaled Barakat Chami V. U.B.A. Plc (2010) 6 NWLR (Pt. 1191) 474 SC was first originated in the High Court in 1999 but the judgement of the Supreme Court was only delivered 11 years after in 2010. Similarly, in the Supreme Court case of Chief Peter Amadi Nwankwo \& Anor v. Ecumenical Development Co-Operative Society (EDCS) U.A. (2007) 5 NWLR (Pt.1027) 377, litigation on a loan due to be repaid by the appellants in 1990 lasted up to 2007 when the apex court delivered its judgement on an issue of procedure without delving into the substantive issue of the debt.
} 
The vast majority of borrowers in Nigeria unable to access credit from formal institutions turn to informal lenders to meet their needs. On the positive side, it is an easier place to access loans for people who may not be able to meet the requirements of formal lenders by reason of working in the informal economy (Babajide 2011, p. 24; Diaz-Moriana and O'Gorman 2013, p. 630). Very often, the lender and borrower belong to the same family, social circles, labour union, or share a certain sense of community (Heath and Calvert 2013, p. 1120). This relational model presents additional advantages potentially, in terms of fairer interest rates, the flexibility of repayment, or a distinct level of lender compassion that is often not afforded by formal contracts (Heath and Calvert 2013, p. 1120). While the informal market thrives because of its informational advantage over the formal sector (Bell et al. 1997, p. 557; Kochar 1997, p. 339), from a consumer protection perspective, it presents a greater difficulty for monitoring the welfare implication of credit contracts for borrowers. In the absence of regulation, lenders set the terms and consumers are often subjected to their whims and caprices (Rona-Tas and Guseva 2018, p. 55). For example, informal contracts are often unwritten and therefore unclear, and lenders often resort to extra-legal means for debt recovery. ${ }^{2}$ The poor socioeconomic backgrounds of the consumers in question create an inequality of bargaining power resulting in welfare reducing transactions.

It must be clarified at this point that higher capital and liquidity requirements are not to blame for consumers' inability to provide formal documentation such as biometric identification cards or valid collateral. However, increased HLA and liquidity requirements compromise the capacity and willingness of formal lending institutions such as commercial banks to invest in learning how to collect and process alternative forms of data that could qualify lower-end consumers for access to credit in the formal market. This happens where banks have lower liquidity and therefore, less incentive to lend to a "riskier pool" of borrowers. It is also evident in the reluctance of traditional lenders to invest in financial technology models that could enable them to serve the poor despite the initial regulatory advantage banks enjoyed over fintech operators and Mobile Telecommunication Companies (TELCOs) in Nigeria. ${ }^{3}$ This is in contrast to policy in some other sub-Saharan African countries where fintech and TELCOs were allowed to compete with banks for banking business (International Finance Corporation 2012, p. 34).

CBN regulation such as the Mobile Money Regulations of 2009 expressly excluded TELCOs from accepting mobile money deposits from depositors or engaging in activities that mimicked traditional banking, e.g., lending. In 2018, the CBN introduced new Guidelines for Licensing and Regulation of Payment Service Banks in Nigeria, which allow TELCOs to undertake some banking activities but expressly prohibited lending. ${ }^{4}$ Ironically, TELCOs have proved to be more adept at serving lower-end consumers in developing countries with MPESA and MoKash revolutionizing financial services delivery to the poor in Kenya and Rwanda, respectively (MTN Rwanda 2018). The same has also been implemented in Ghana with

\footnotetext{
${ }^{2}$ Illegal debt recovery practices by lenders and law enforcement agencies involving the intimidation, physical violence, detention, arbitrary seizure of borrowers' assets, and other breaches of the fundamental rights of borrowers have been documented in a long line of case law in Nigeria. See Economic \& Financial Crimes Commission V. Diamond Bank Plc \& Ors (2018) LPELR-44217(SC). See also A. G. Plateau State v A. G Nasarawa (2005) 129 LRCN 1523 at 1531; UNIBIZ v Commercial Bank (2005) 125 LRCN 1484 at 1495 ; University of Ilorin v Oyelana (2001) FWLR (Pt. 83) 2193 at 2209.

${ }^{3}$ See for example The CBN's Guidelines for the Regulation of Agent Banking and Agent Banking Relationships in Nigeria 2013; the Mobile Money Regulations 2009; and the Guidelines for Licensing and Regulation of Payment Service Banks in Nigeria 2018.

${ }^{4}$ Para. 4, Guidelines for Licensing and Regulation of Payment Service Banks in Nigeria 2018
} 
reasonable success (Ghana National Communications Authority 2018). The lack of competition from other service providers and consequent low investment in an algorithm-driven process mean that Nigerian banks continue to rely on traditional screening methods such as requirements that borrowers have a white-collar job with the salary account domiciled in the bank or owned valid collateral before loan applications receive consideration.

The ownership of valid collateral is historically significant for understanding the disparity in credit advances to elite and lower-end borrowers. For one, the legal process for the determination of valid collateral is unfair to the poor, especially borrowers who hold assets that are not in the acceptable legal form. The reality is that many "poor" borrowers own private properties such as land, houses, and apartments for which they have not obtained a formal certificate of occupancy or right of occupancy from the state, and in many cases have built houses without official government permits. The injustice of this is in two dimensions. First, similar to the dual economy described earlier, the country operates two systems of land ownership where customary titles, registered titles, and instruments are recognized as conferring equitable rights (dead capital), whereas only a government certificate or right of occupancy (depending on whether the land is classified as urban or rural) confers legal title (live capital). Less than 3\% of Nigerian land has registered titles (Presidential Technical Committee on Land Reform 2013), meaning poorer borrowers are more likely to hold only customary titles and build without government permits and consequently enjoy less access to formal credit. The injustice of this is not that creditors and regulators privilege asset holders over non-asset holders in terms of credit access, but that the type of ownership available to the poor (equitable rights) is rendered ineligible by regulation and by implication market realities around contract enforcement:

... Most of the poor already possess the assets they need to make a success of capitalism. ..But they hold these resources in defective forms: Houses built on land whose ownership rights are not adequately recorded, unincorporated businesses with undefined liability, industries located where financiers and investors cannot see them. Because the rights to these possessions are not adequately documented, these assets cannot readily be turned into capital, cannot be traded outside of narrow local circles where people know and trust each other, cannot be used as collateral for a loan, and cannot be used as a share against an investment. (de Soto 2017, p. 12).

The second dimension of injustice is the fact that most holders of equitable title do not hold the legal title for no failure of theirs but rather are victims of an inefficient regulatory regime, and a failure of the government to attend to the housing needs of her citizenry. The Land Use Act 1978 requires the Governor to consent to not just the initial allotment of the land but to any subsequent assignment of interest by the initial allottee to subsequent buyers. Failure to do so means that such a buyer can only acquire an equitable interest and because of the sheer administrative demands of procuring the governor's consent, parties to most land transactions seek to avoid the process using legal instruments such as a Power of Attorney which while not an instrument of transfer of legal title and therefore not valid for collateral, gives effective ownership to the buyer. According to de Soto, legislation such as the Land Use Act 1978 represent a legacy of colonial law in most developing countries that is "tilt[ed] toward protecting ownership," and "why most of the assets in developing and former communist countries have slipped out of the formal legal system in search of mobility." (de Soto 2017, p. $38)$. 
The rich, in contrast, can manipulate the application process through bribery and other corrupt practices or through innocuous behaviours such as tipping officials which guarantee that the process for getting the governor's consent is expedited. This is not to mention the unique case of customary title holders who are unaware of the Land Use Act due to illiteracy, and are unable to navigate the process or to afford the administrative fees needed to apply for the governor's consent. De Soto highlights this hardship eloquently thus:

But they are only a tiny minority-those who can afford the expert lawyers, insider connections, and patience required to navigate the red tape of their property systems. The great majority of people, who cannot get the fruits of their labor [sic] represented by the formal property system, live outside Braudel's bell jar. (de Soto 2017, p. 42).

While regulators have moved increased capital requirements for banks, a regulation that supports banks to use capital to increase liquidity is not in place. Instead, regulators in Nigeria have focused narrowly on the physical assets of financial institutions, and increasing tangible capital without much effort to channel the incorporeal productive potential of the capital towards financial inclusion initiatives. For instance, there is no coherent regulatory framework for securitization in Nigeria. However, from a credit user perspective, there is no regulatory effort to assist the poor who are undercapitalized by holding assets in unacceptable legal forms.

Beyond the procedural injustice of collateral requirements, excessive reliance on collaterals for several years before the 2009 banking crisis created a situation where the supply of credit was perversely increased to the top end of the market, while credit to the bottom end (e.g., consumer lending and lending to MSMEs) was rationed. Standard economic analysis suggests that lenders respond to adverse selection by setting the interest rate so low as to be attractive to "good" borrowers, and control the risk of default by "bad" borrowers by rationing credit to both high and low-risk borrowers (Stiglitz and Weiss 1981, p. 408). In Nigeria, possession of collateral meant a low-risk assessment. According to the Central Bank of Nigeria, a group of 250 rich borrowers accounted for USD 231.4 million of the total NPL sum of USD 7.5 billion (CBN 2009). These borrowers deemed "good" defaulted because a good lot of the collaterals were overvalued in an overly speculative real estate market, and as AMCON would later find out, a substantial proportion of recovered collaterals were illiquid. It was also not surprising that many borrowers were insensitive to the high rate of interest (Jibrin et al. 2015, p. 14) as they acted in cahoots with bank CEOs and Managing Directors and had no intention of repaying the loans ab initio. ${ }^{5}$ In essence, the system that was designed to keep out poor, nonasset holders from borrowing, adversely selected rich but bad borrowers. There is an information asymmetry problem resulting in reforms that have further constrained access to credit by non-collateral or white-collar job holders (Ramsay 2012, pp. 42-44).

Consumers of informal credit suffer other forms of disadvantage that are equally welfare reducing. Lenders in informal markets often cannot provide the sums required by borrowers, whereas consumers' options are finite as they tend to have a limited social network and lack the financial means to invest in the social capital to expand this network (Yuan and Xu 2015, p. 232). It is also important to note that consumer loans in developing countries are frequently used for purposes that qualify as investment rather than "consumption." For example, loans to MSMEs may be spent on farming to provide food for the family (which could also be sold for profit) or on a child's fees to attend a nursery so the mother could attend to her small business.

\footnotetext{
${ }^{5}$ See for instance judgments in Federal Republic of Nigeria v. Dr. (Mrs) Cecilia Ibru FHC/L/297C/2009; Intercontinental Bank v. Erastus Bankole Oladipo Akingbola and others 2009 Folio 1680
} 
Loans for investment or production, as opposed to consumption are usually subsidized by the government but because of credit rationing and the absence of regulation to curtail loan concentration, only an elite class with the right collateral and payslips get to access such loans which some go on to on-lend to informal consumers at a higher interest rate (Floro and Yotopoulos in Roumasset 1992, p. 2184).

\section{Informal Credit and Systemic Risk}

We have examined the different ways that regulation undermines consumer welfare by pushing consumers out of the formal market where there is prudential oversight of products, and into the informal where regulatory standards are neither clear nor strongly enforced. The actions of regulators and individual banks to protect solvency can also generate externalities which create or increase systemic risks to the financial system (Caruana 2010). For example, informal borrowing can impair the quality of collateral used to borrow in the formal market where an informal lender takes over and depletes the asset before the formal lender could enforce the collateral. Consumer subscription to safe products in the formal market, and unsafe products in the informal market, raises the overall risk of default, if because of the unsafe product they default on the safe product (Bar-Gill and Warren 2008, p. 5). Indeed dual market economies produce information asymmetry (most informal debt is not captured by credit bureaus) that can lead to an oversupply of credit through multiple lending (Degryse et al. 2012, p. 2) especially to the rich borrowers responsible for the Nigeria banking crisis. The focus of the G-20, the Financial Stability Board, the OECD High Level Principles on Consumer Credit, the World Bank's Good Practices on Consumer Protection, and the UN Guidelines on consumer protection indicate a broad recognition of the potentially destabilizing character of credit to the economy (European Parliament and Council Directive 2008/48/EC; OECD 2011, p. 4; United Nations Guidance on Consumer Protection 2016, p. 3; World Bank 2017, p. 8, 54, 73). The quality of protection and the scope of protected consumers in developing countries remain open to debate.

Over the last three decades, three important events have conditioned formal lenders in Nigeria to restrict credit supply to elite borrowers or less than $6 \%$ of the adult population (Euromonitor International 2018). These events include the introduction of the Structural Adjustment Programme (SAP) of the World Bank/IMF in 1983 which emphasized privatization, liberalization, and formalization; the banking consolidation exercise of the CBN; and the BASEL II reforms (Sanusi 2010, p. 116; World Bank 1989, p. 3). Prior to SAP, the Nigerian government required commercial banks to lend to rural consumers whose private financial institutions would not ordinarily direct resources (World Bank 1989, p. 3). SAP, however, forced the government to amongst other things dismantle interest rate controls and regulatory mandates directing credit allocation. One implication of these changes and increased sensitivity to systemic risk concerns is that lower-end consumer borrowers in Nigeria owe too little, and therefore pose very little risk to the financial system.

While the exact meaning of "systemic risk" remains unsettled (Cerutti et al. 2012; IMF 2009), it includes the risk that the entire financial system may fail, causing a general economic collapse, as opposed to risk associated with an individual part of the system (Danielsson 2013). The potential risk of consumer lending to the stability of the financial system is higher for advanced economies, such that regulatory responses that might be justifiable in such economies, and the urgency attached thereto, will not necessarily be logical in the case of developing markets. According to the IMF ( 2017, p. 55), "the negative medium-term consequences of 
increases in household debt are more pronounced for advanced than for emerging market economies." In theory, the CBN's banking reforms heralding more stringent regulation of the formal financial sector operates to responsibilize lenders and to rein in irresponsible lending. But with credit rationing rampant, the reforms compromise consumer safety because informal lenders to whom consumers turn are not within the purview of regulation and therefore are not responsibilized in any real sense. The lack of transparency in that market makes it difficult not only to measure the welfare benefits of credit products but also makes it harder to monitor leverage levels.

\section{Why Access Remains Important to the Poor}

Access to safe credit products offers opportunities for households to accumulate wealth and expand job opportunities (Bar-Gill and Warren 2008, p. 5). Credit cards, for example, render payments for the purchase of goods and services convenient by reducing the amount of cash at hand with the attendant exposure to the risk of theft or loss, and the risk of botched transactions as a result of insufficient cash (Committee on Consumer Credit Law 1971, p. 117). People borrow to smooth temporarily unstable income (Guerrieri and Lorenzoni 2011, pp. 14291430), and particularly in times of wider economic downturn (Bertrand et al. 2010, p. 302; Morgan et al. 2012, p. 519; Morse 2011, pp. 28-29), access to formal credit has a net positive impact on the poor (Banerjee et al. 2015, p. 1; Lerner and Tufano 2011, p. 41).

The welfare risk of unregulated credit products is a different story. Access to unsafe or unregulated credit products can have devastating welfare effects on consumers. Unregulated lenders are often in the habit of soliciting customers and encouraging them to borrow, sometimes with attractive terms that tend to grow consumers' collective appetite for borrowing, plunging families and businesses into excessive leverage for mostly uneconomic reasons (Mazer et al. 2014, p. 1). The built-in responsible lending requirement that Nigerian banks must not deduct beyond $35 \%$ of employee income does not apply to workers in the informal market ${ }^{6}$ which means that some borrowers could easily become over-indebted or entrapped by loan sharks. Consumer lending also has social detriments that are sometimes characterized as the modern equivalent of slavery or peonage (James 2015, p. 2).

Access to consumer credit in the absence of effective regulation is not only detrimental to the individual consumer but compromises the stability of the financial system. Credit is a product, and like all products, it must satisfy set standards. The requirement for standards regulation in credit markets is as salient as it would be in automobile, pharmaceutical, food, and construction industries, amongst others (Bar-Gill and Warren 2008, p. 5). Consumer credit products like credit cards and payday loans can create financial distress for borrowers, economic losses for innocent third parties, and a state of economic instability for a country's economy (Bar-Gill and Warren 2008, p. 5; Campbell et al. 2012, p. 1224; Department of Defence 2006, pp. 39-41; Eckholm 2006; Financial Conduct Authority 2017, p. 14; Harris 2011, p. 353; Melzer 2011, p. 517; Morgan et al. 2012, p. 519; Skiba and Tobacman 2008, p. 2; Zinman 2014). This is why they are regulated and why unregulated products can be dangerous. Apart from the absence of responsible lending obligations that seek to protect consumers from predatory lending, informal credit users are highly vulnerable to behavioural exploitation as loan sharks operate a model that seeks to extract maximum interests from

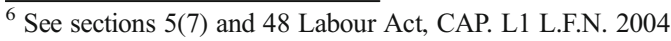


desperate, poor, and boundedly rational borrowers. We must emphasize that borrowers in the formal market are not immune to behavioural exploitation, but the lack of regulatory oversight of the informal market significantly increases the level of consumer vulnerability (James 2015, p. 2).

\section{How Regulators Can Protect Lower-end Borrowers in Nigeria}

The earliest reforms to increase financial inclusion in Nigeria dates to the proliferation of Micro Finance Banks in 2005 as a response to the World Bank's financial inclusion agenda to curb poverty (CBN 2011, pp. 4-7). This coincided with the recapitalization of commercial banks (and the consequential liquidity shortages that meant lower access for lower-end consumers in the commercial bank segment). More recently, however, legislation has been passed to ease access by all categories of consumers but especially the poor. The reforms include the enactment of the Credit Reporting Act 2017 and The Secured Transaction in Movable Assets Act 2017.

\section{(i) The Credit Reporting Act}

Until the 1980s, Nigerian credit markets remained excessively regulated, and the government maintained cosy relationships with the country's main banks and institutions, often tainted with market-hampering corruption and cronyism (Research Republic 2016, p. 58). According to the Central Bank, the late 1980s and early 1990s witnessed rising non-performing credit portfolios in banks and these significantly contributed to the financial distress in the banking sector (Sanusi 2010, p. 2). A significant number of predatory debtors existed in the banking system, and their survival strategy mostly involved the abandonment of their debt obligations in some banks only to contract new debts in other banks (Sanusi 2010, p. 2). Regulators lacked access to sufficient credit information, and this made it difficult to consistently classify credits granted to certain borrowers and their associated companies.

In order to address this problem, a credit registry called the Credit Risk Management System (CRMS) was established by sections 28 and 29 of the CBN Act No.24 of 1991 (as amended). The enabling legislation empowered the $\mathrm{CBN}$ to obtain from all banks returns on all credits with a minimum outstanding balance of NGN 100000.00 (now N 1 million and above of principal and interest), for compilation and dissemination by way of status report to any interested party (i.e., operators or regulators) and compliance became mandatory (CBN 2018). This, however, failed to address information asymmetry in the consumer credit market as most consumer borrowings fall below that threshold, and consequently impacted negatively on access by the poor.

The enactment of the Credit Reporting Act 2017 (CRA) thus addresses the information problem in the consumer credit market. The main objectives of the Act are to promote access and risk management, increase transparency through information sharing, and establish reporting standard, ultimately enhancing responsible lending and borrowing. Sections 1 and 12 (f) of the Act stops short of making "responsible lending and borrowing" a legal requirement but attempts to responsibilize lenders by requiring lenders to obtain a credit report from at least one of the licensed credit bureaux before granting any form of credit. While the CRA is not explicit on the penalties for non-compliant lenders, Sections 23 and 27 make noncompliance with the provisions of the Act punishable by a fine (on lending institutions) and 
imprisonment upon conviction for authorizing officers. It is also not clear if lenders would be penalized for granting credit to a borrower shown to be over-indebted by a credit report. Experience from the Nigerian banking crisis has shown that lenders tend to focus more on the margins on the principal loan sum than they are worried about losing the principal.

With the current restrictive access to credit in Nigeria, the reticence on affordability assessment thresholds is understandable. Nevertheless, the reluctance to set such a strict standard stands in contrast with emerging regulatory attitudes in other jurisdictions. An increasing number of countries have introduced a statutory requirement to perform affordability assessments in recent years, such as the EU Directive on Consumer Credit (2008) and the Dodd Frank Act in the United States. ${ }^{7}$ Similar requirements are now in place in South Africa, Mexico, Australia, and Uganda, amongst others with a few exemptions for educational loans.

Nigeria's approach is, however, similar to that of the UK. Under the UK's Consumer Credit Act 2006 which amends the 1974 Act, the Credit Commissioner is empowered to suspend irresponsible lenders from market participation, and courts are empowered to void "extortionate" (now supplanted by an unfair relationship test), "grossly exorbitant" credit contracts, or contracts that run against the principle of fair dealing. But in practice, even with greater flexibility under the 2006 amendment, the courts have been very conservative, in most cases interpreting ambiguous terms in favour of the lender (Fairweather 2012, p. 84). The similarity of approach to the UK is also partially indicative of the continuing influence of the English legal system on post-colonial Nigeria.

The most important contribution of the Credit Reporting Act 2017 to the development of consumer credit market in Nigeria is contained in section 27 which expands reporting obligation to a broad segment of informal market operators including co-operative societies that offer credit to small, medium, and microenterprises, including individual consumers (Davel 2013, p. 1). This segment of the market is responsible for originating most credit facilities to consumers and the most opaque. Creditors in informal credit markets are more likely to be irresponsible lenders with the aim to exploit poor hapless borrowers, but they provide often much needed funds to their targets that they otherwise could not access in the mainstream market (Wilson 2008, p. 91). The CRA therefore potentially introduces much needed transparency into this market and also encourages mainstream lenders to lend to the category of individuals that seek out loans in this market.

\section{(ii) The secured transaction in movable assets Act 2017 (STMA)}

The STMA is the second legislation in the reforms aimed at promoting financial inclusion, especially access to consumer credit. The Act establishes via Sections 3 and 8, a National Collateral Registry that makes it possible for lenders to register a "Financing Statement" over movable collateral submitted by borrowers to secure a loan. Sections 12-18 of the STMA also imposes the obligation to register a financing statement on the lender or someone acting on their behalf. A financing statement must fully describe the identities of the lender and borrower, the particulars of the loan (principal, term, interest, etc.), and the particulars of the collateral. As soon as the creditor files this statement with the registrar, a confirmation certificate is issued, creating a charge on the registered asset. This Act is expected to improve the creditworthiness of individuals who owned movable assets of value but hitherto unable to

\footnotetext{
${ }^{7}$ See Article 8, Directive 2008/48/EC of the European Parliament and of the Council (Official Journal of the European Union, L 133/66)
} 
access credit because such assets were not registrable. Ownership of collateral is a significant determinant of access to credit (Bertola et al. 2006, p. 8). The STMA thus removes barriers to accessing finance by millions of Nigerian farmers (e.g., livestock owners), artisans, and small scale traders, particularly women who in many local customs, were unable to own fixed assets.

The STMA also attempts to minimize the problem of information asymmetry in the consumer credit market which had built up as a result of a historically large and active informal market. Borrowers tend to use the same collateral to access multiple loans while lenders tend to use unorthodox tactics for debt recovery, including resort to violence and bribing rogue police officers to deploy strong-arm tactics on their behalf. In theory, Section 8 of the STMA undermines illegal seizure of collateral as mere possession without registration of collateral entitles a lender to no rights or title, while Section 6 (2) enables formal lenders to enforce registered collateral into the hands of a third party. This is designed as a disincentive to loan sharks who rely on the arbitrary seizure of collateral to survive in the market. Knowing that those assets could be traced into their hands, make them liable to the creditor, and shine an unwelcome spotlight into their business operations, their rational response is to avoid lending or lending on illegal terms. The STMA addresses the information asymmetry of the consumer loan market in two respects. First, it becomes difficult to use one collateral for multiple loans secretly. Secondly, lenders are better informed to assess the material quality of collateral submitted and how their legal rights compare to the borrower's existing creditors. This is especially significant as it minimizes systemic risk stemming from excessive lending. In practice, however, it may not improve lending to the poor because lenders still have to factor in the cost of tracing collateral into third party hands, and the risk is significant because of the problem of slow judicial process highlighted earlier, and the uncertainties of dealing with an informal lender who may not have a clear business address. Furthermore, although the registration procedure appears simple and straightforward, the STMA does not stipulate a time frame within which a financing statement may be registered. This has led legal practitioners to raise questions about the priority of the lender's registered interest vis-à-vis interests created under parallel registries under section 179 of the Companies and Allied Matters Act and the Bill of Sales Law of the various states in Nigeria (Ajayi 2017, p. 1).

The other relevant reform introduced by the STMA is the dispute resolution process. Section 41 of the STMA establishes a Mediation and Dispute Resolution Panel regulated by the CBN. This empowers poor borrowers to seek redress where their assets are unlawfully seized by lenders without having to worry about the cost of litigation, which is often protracted.

\section{Are the Reforms Adequate?}

The credit regulations discussed above have aimed to promote market resilience, transparency and risk mitigation, fair treatment, and effective recourse for consumers although these outcomes are the hallmarks of consumer protection, the assumptions that birth these reforms, however, require closer scrutiny within the context of an emerging market.

The first assumption is that with greater transparency, there will be a greater supply of credit (Rona-Tas 2016, p. 199). Credit reporting helps to amongst other benefits mitigate adverse selection; punish defaulters through deterrence hence decrease moral hazard; loosen information monopoly of lenders over borrowers; and reveal overextended clients as it reports the entire debt profile (Rona-Tas 2016, p. 203). The assumption fails to account for the possibility 
of formal lenders opting to lend to a worse selection from a better pool of borrowers over a better selection from a worse pool, regardless of the lessons of the 2009 crisis. Consumers are thus subjected to a possibility of being refused credit regardless of their stellar or non-existing credit history (Rona-Tas 2016, p. 202). The reliability of the credit reporting system in Nigeria continues to be undermined by low data integrity, delays in reporting, and low participation of non-bank financial institutions including informal lenders who account for the most lending (Mylenko 2008, p. 11; Popoola 2018). Even where low-income individuals do have a positive credit report, they still have to contend with the bias of lenders against consumer lending in comparison to corporate or rich borrowers (Popoola 2018). Lenders rank the (un)known risk of lower-end borrowers (information asymmetry) above the known risk (moral hazard) of wealthy borrowers, i.e., the predictable reluctance of rich, powerful, and influential borrowers to repay loans on time.

The second assumption is that with effective market competition and a collateral registry, consumers would be able to access finance in the formal markets. One setback to this assumption is the failure of regulators to recognize the need to play an increasing role in addressing liquidity shortages in the financial sector. Although the welfare benefits of financial inclusion have been questioned by critics (Lazarato 2016, p. 61; Soederberg 2014, p. 27, 46; Stern 2016), Nigeria can promote financial inclusion by adopting policies that aim to eliminate the obstacles to lower-end borrowers highlighted in previous sections. Financial inclusion in this context would not be a substitute for social welfare programmes or creating jobs with decent wages, but a component of these broader objectives. For example, OECD countries responded to the GFC by extending consumption packages, adjusting tax policies to stimulate demand, recapitalizing banks with explicit safeguards to enhance banks' capacity for financing SMEs including public credit guarantees, insurance, factoring for receivables, and better payment discipline by governments (Sinha et al. 2011, p. 23). Additional measures included cutting employment taxes or social security charges and extended temporary unemployment programmes. In emerging market economies, India, for example, exempted hard-hit sectors from compliance with the risk weights and general provisions on capital exposure (Sinha et al. 2011, p. 23).

In Nigeria, the federal government failed to implement fiscal policy initiatives to supplement the CBN's response (to bail out big time debtors), especially to guarantee to lend to SMEs and consumers. This type of intervention reinforces the moral hazard of Too Big To Fail and sends the wrong signal to lenders that it is safer to lend big to rich businessmen no matter the risk than lend small to SMEs and consumers as the latter would not be bailed out. Rather than introducing a stimulus programme aimed at boosting consumer lending, the Federal Government introduced the Treasury Single Account in 2015 effectively transferring all government accounts from deposit money banks to the CBN. The policy aims to promote government accountability and transparency (Agbo et al. 2016, p. 185). It, however, exacerbated the liquidity crisis in the economy, which further undermines the government's financial inclusion agenda.

Finally, the CBN's bank-led mobile banking model further constrains access by lower-end borrowers as it prevents TELCOs and fintech start-ups from carrying on lending activities. ${ }^{8}$ There is a compelling case for liberalizing the licensing regime to accommodate different categories of operators including TELCOs, banks, and Fintech start-ups. This is essential for competition purposes but also because different operators can deliver complementary services

${ }^{8}$ Mobile Money Regulatory Framework 2009 
for consumers in a way that a binary approach could not. It is an opportunity to extend prudential oversight to a safer type of informal credit. First, TELCOs in Nigeria have far wider coverage and distribution of access points compared to banks and thus better positioned to reach rural communities where formal financial services are currently unavailable. According to the Nigeria Inter-Bank Settlement Systems PLC (NIBSS), a total number of 51.7 million bank account holders had been assigned biometric verification numbers by February 2017 compared to 154.1 million phone subscribers in the same period in 2017 and 93.3 million unique subscribers (Nigerian Communications Commission 2018). Despite Nigeria's multiSIMs culture which means that there are more active connections than individual subscribers (GSMA 2017), TELCO access points across the country exceed commercial bank access points.

Somalia and Kenya provide impressive examples of the gains of TELCO participation in the mobile money market. In Somalia, bank account penetration stands at 15\%, but TELCOled mobile money account penetration is over $73 \%$ despite the insecurity in Somalia (Firestone et al. 2017). Consumers stand to benefit from TELCO participation in difficult business terrains, especially northeastern Nigeria where Boko Haram terrorists have forced many banks and financial institutions to close shop. Secondly, TELCOs have a larger customer base, and the marginal cost of extending banking services to them is lower compared to banks. Thirdly, fintech companies have demonstrated superior ability to deploy algorithms in creditworthiness assessments in a way that commercial banks in the country have not been able to achieve. As one of the biggest challenges to fintech product uptake by consumers is lack of awareness, TELCOs have the advantage in terms of advertising as all it takes is an SMS delivered to customers at no extra costs. There is a net benefit for borrowers from an all-inclusive market. The new guidelines on Payment Service Banks do not go far enough because of specific restrictions imposed to "level the field" for all competitors. The guidelines impose the same documentation requirements for banks and fintech and systematically neutralizes the efficiency gain from innovation that fintech lenders could leverage for lower product prices (Saigal 2019).

\section{Conclusion}

BASEL II capital and liquidity requirements to ensure strong and stable financial systems inadvertently undermine the drive for financial inclusion in Nigeria. This is consistent with a broader literature that finds a dissonance between international rulemaking and the regulatory needs of developing markets. This dissonance is a logical consequence of excluding regulators from developing countries from the roundtable where financial regulatory policy is conceived and adopted. In the context of lending to lower-end consumers in Nigeria, as lending criteria become more stringent, more consumers of finance are pushed into informal markets because of liquidity-induced credit rationing. Overall, consumer protection is compromised because stronger consumer protection rules for the formal sector benefits borrowers from formal institutions who constitute the minority of borrowers in all markets. The majority of borrowers operate in informal markets largely without prudential oversight and conduct supervision.

The existence of a larger informal market for the poor and a smaller formal market that caters mostly to elite borrowers is unfair because it ensures that the poor continue to pay more for credit and highly vulnerable to ruthless lenders. The disparity in access is predicated on the latter's private property rights and ability to provide valid collateral whereas the former are 
excluded not because they do not own properties but that they hold dead capital. Regulators, therefore, must initiate regulation that transforms "dead capital" into "live capital." Regulators must also come to terms with the urgent need to address loan concentration and to stimulate competition by allowing TELCOs and fintech companies to carry on banking business because of their superior knowledge of lower-end markets. This will increase the Central Bank of Nigeria's burden of prudential oversight, but the costs to consumers of exposure to loan sharks, given the sheer size of the informal market in Nigeria, and the benefits derivable from regulatory protection outweigh that burden.

Acknowledgements I wish to express my deep gratitude to Professor Iain Ramsay who was kind enough to offer advice and read through the manuscript.

Open Access This article is distributed under the terms of the Creative Commons Attribution 4.0 International License (http://creativecommons.org/licenses/by/4.0/), which permits unrestricted use, distribution, and reproduction in any medium, provided you give appropriate credit to the original author(s) and the source, provide a link to the Creative Commons license, and indicate if changes were made.

\section{References}

Agbo, P. O., Jugu, Y. G., \& Okwoli, A. A. (2016). Effects of treasury single account on performance and survival of deposit money banks in Nigeria. International Journal of Management Science Research, 2(1), 185-198.

AMCON. (2018). AMCON slumps to full-year loss. Retrieved from http://amcon.com.ng/news-story.php?n=13 . Accessed 26 September 2018.

Anderson, K. (2005). Squaring the circle? Reconciling sovereignty and global governance through global government networks. Harvard Law Review, 118(1255), 1278.

Apati, S. (2012). The Nigerian Banking Sector Reforms: power and politics (1st. Ed.). Basingstoke: Palgrave Macmillan Studies in Banking and Financial Institutions.

Ajayi, O. (2017). The secured transactions in movable assets act: Key highlights and impact on the existing legal landscape. Retrieved from https://www.olaniwunajayi.net/wp-content/uploads/2017/11/Understanding-theSecured-Transactions-in-Movable-Assets-Act-6.pdf". Accessed 27 April 2019.

Babajide, A. A. (2011). The relationship between the informal and formal financial sector in Nigeria: A case study of selected groups in Lagos metropolis. International Journal of Research in computer application and management, 1(10), 24-32.

Banerjee, A., Karlan, D., \& Zinman, J. (2015). Six randomized evaluations of microcredit: Introduction and further steps. American Economic Journal: Applied Economics, 7(1), 1-21.

Bank for International Settlements. (2010). Macroeconomic assessment group - Final report assessing the macroeconomic impact of the transition to stronger capital and liquidity requirements. Retrieved from https://www.bis.org/publ/othp12.pdf. Accessed 31 Jan 2018.

Bank for International Settlements. (2017). Basel Committee on Banking Supervision. High-level summary Of Basel III reforms. Retrieved from https://www.bis.org/bcbs/publ/d424_hlsummary.pdf. Accessed 9 September 2019.

Bar-Gill, O., \& Warren, E. (2008). Making credit safer. University of Pennsylvania Law Review, 157(1), 1-101.

Bell, C., Srinivasan, T., \& Udry, C. (1997). Rationing, spillover, and interlinking in credit markets: The case of rural Punjab. Oxford Economic Papers, 49(4), 557-585.

Bernanke, B. S., Geithner, T. F., \& Paulson, H. M. (2019). Firefighting: The financial crisis and its lessons. New York, NY: Penguin Books.

Bertola, G., Disney, R., \& Grant, C. (2006). The economics of consumer credit. Cambridge, MA: The MIT Press.

Bertrand, M., Mullainathan, S., Karlan, D., Shafir, E., \& Zinman, J. (2010). What's advertising worth? Evidence from a consumer credit marketing field. Quarterly Journal of Economics, 125(1), 1-45.

Brummer, C. (2010). Post-American securities regulation. California Law Review, 98(327), 384.

Campbell, D., Tufano, P., \& Martinez-Jerez, A. (2012). Bouncing out of the banking system: An empirical analysis of involuntary bank account closures. Journal of Banking \& Finance, 36(4), 1224-1235.

Campos, N. F., \& Nugent, J. B. (1999). Development performance and the institutions of governance: Evidence from East Asia and Latin America. World Development, 27, 439. 
Capoccia, G. (2015). Critical junctures and institutional change. In J. Mahoney \& K. Thelen (Eds.), Advances in comparative-historical analysis (pp. 147-179). Cambridge: Cambridge University Press.

Caruana, J. (2010). Systemic risk: How to deal with it? Bank for International Settlements. Retrieved from https://www.bis.org/publ/othp08.htm. Accessed 17 Oct 2019.

Central Bank of Nigeria. (2009). Advertorial. Retrieved fromhttps://www.cbn.gov. ng/Out/publications/pressRelease/GOV/2009/ADVERTORIAL_18082009.pdf. Accessed 1 Feb 2018.

Central Bank of Nigeria. (2010). Financial stability report January 2009 - June 2010. Retrieved fromhttp://www. cenbank.org/OUT/2010/PUBLICATIONS/BSD/FINANCIAL\%20STABILITY\%20FINAL\%20TO\%20 PRINTER\%20-\%2015102010.PDF. Accessed 10 October 2019.

Central Bank of Nigeria. (2011). Microfinance policy framework for Nigeria (Revised - April 29, 2011).

Cerutti, E., Claessens, S., \& McGuire, P. (2012). Systemic risks in global banking: What can available data tell us and what more data are needed? Bank for International Settlements. Retrieved from http://www.bis. org/publ/work376.pdf . Accessed 6 Oct 2018.

Chike-Obi, M. (2014). Re: Public hearing. Senate Committee on Banking, Insurance and Other Financial Institutions Public Hearing on proposed amendment to Asset Management Corporation of Nigeria (AMCON) Act of 2010, Abuja, Nigeria. Retrieved from http://www.amcon.com. ng/documents/MDsSpeechatSenate.aspx . Accessed 9 Oct 2018.

Committee on Consumer Credit Law. (1971). Consumer credit: Report of the Committee- Volume 1 (Cmnd. 4596).

Comparato, G. (2016). The design of consumer and mortgage credit law in the European system. In I. N. Domurath, H. W. H. Geraint, Consumer Debt and Social Exclusion in Europe (pp. 9-10). Abingdon: Taylor and Francis.

Danielsson, J. (2013). Global financial systems: Stability and risk. Harlow: Pearson Education Limited.

Davel, G. (2013). Regulatory options to curb debt stress. CGAP.

Degryse, H., Ioannidou, V., \& Schedvin, E. (2012). On the non-exclusivity of loan contracts: An empirical investigation. Sveriges Riksbank Working Paper Series No. 258.

Department of Defence (2006). Report on predatory lending practices directed at members of the armed forces and their dependents, 39-42.

de Soto, H. (2017). Excerpts from the mystery of capital. Brigham-Kanner Property Rights Conference Journal, $6,9-71$.

Eckholm E. (2006, December 23). Seductively easy, payday loans often snowball. New York Times. Retrieved from https://www.nytimes.com/2006/12/23/us/23payday.html. Accessed 17 October 2019.

Euromonitor International. (2018). Country Report: Consumer lending in Nigeria. Retrieved from https://www. euromonitor.com/consumer-lending-in-nigeria/report Accessed 27 Apr 2019.

European Commission, (2012). High-level expert group on reforming the structure of the EU banking sector. Retrieved from: http://ec.europa.eu/internal_market/bank/docs/high-level_expert_group/liikanenreport/final_report_en.pdf. (accessed 5 October 2018).

Fairweather, K. (2012). The development of responsible lending in the UK consumer credit regime. In J. Devenney \& M. Kenny (Eds.), Consumer credit, debt and investment in Europe (pp. 84-110). Cambridge: Cambridge University Press.

Financial Conduct Authority (2017). Credit card market study: Consultation on persistent debt and earlier intervention remedies. CP17/10.

Firestone, R., Kelly, T., \& Rifon, A. (2017). A game changer-the prospects and pitfalls of mobile money in Somalia. Retrieved fromhttp://blogs.worldbank.org/nasikiliza/a-game-changer-the-prospects-and-pitfalls-ofmobile-money-in-somalia . Accessed 27 April 2019.

Floro, S. L., \& Yotopoulos, P. A. (1991). Informal credit markets and the new institutional economics: The case of Philippine agriculture. In J. A. Roumasset, (1992). Book reviews: Agricultural and natural resource economics. Journal of Economic Literature, 30(4), 2184-2185.

Ghana National Communications Authority. (2018). Mobile data figures for July 2018. Retrieved from https://www.nca.org.gh/industry-data-2/market-share-statistics-2/data-3/ . Accessed 16 Oct 2018.

Gottschalk, R. (2015). What financial regulation for stability and financial inclusion in Africa? The views of regulators of Ethiopia, Kenya and Lesotho. Overseas Development Institute Working paper 414. Retrieved fromhttps://www.odi.org/sites/odi.org.uk/files/odi-assets/publications-opinion-files/9590.pdf . Accessed 31 Jan 2018.

GSMA. (2017). GSMA Mobile Economy Report 2017. Retrieved from https://www.gsma. com/subsaharanafrica/resources/the-mobile-economy-2017 Accessed 17 Oct 2019.

Guerrieri, V., \& Lorenzoni, G. (2011). Credit crises, precautionary savings, and the liquidity trap. The Quarterly Journal of Economics, 132(3), 1427-1467.

Hall, P. A. (1993). Policy paradigms, social learning, and the State: The case of economic policymaking in Britain. Comparative Politics, 25(3), 275-296. 
Harris, G. L. A. (2011). Charlatans on the Move. Public Integrity, 13(4), 353-370.

Heath, S., \& Calvert, E. (2013). Gifts, loans and intergenerational support for young adults. Sociology, 47(6), 1120-1135.

HM Treasury (2009). Reforming financial markets. Retrieved from https://www.gov. uk/government/uploads/system/uploads/attachment_data/file/238578/7667.pdf. Accessed 5 Oct 2018.

Institute of International Finance (2011). The cumulative impact on the global economy of changes in the financial regulatory framework. Retrieved from: https://www.iif.com/system/files/nciseptember2011.pdf. Accessed 24 Oct 2018.

International Finance Corporation (2012). Mobile money scoping country report: Nigeria. Retrieved from https://www.ifc.org/wps/wcm/connect/a37edc004e466439a86da87a9dd66321/MobileMoneyScoping_ Nigeria.pdf?MOD=AJPERES . Accessed 16 Oct 2018.

International Monetary Fund. (2009). Global financial stability: Report responding to the financial crisis and measuring systemic risks. Retrieved from Global Financial Stability Report - International Monetary Fund. https://www.imf.org>external>pubs>GFSR>2009/01>pdf>_textpdf. Accessed 5 Dec 2019.

International Monetary Fund. (2017). Regional economic outlook: Sub-Saharan Africa restarting the growth engine. Washington, D.C.: International Monetary Fund.

Jain, S. (1999). Symbiosis vs. crowding-out: The interaction of formal and informal credit markets in developing countries. Journal of Development Economics, 59(2), 419-444.

James, D. (2015). Money from nothing: Indebtedness and aspiration in South Africa. California, CA: Stanford University Press.

Jibrin, M. A., Okorie, G., Okoro, A. S., Dada, E.A., Chiemeke, C., \& Owolabi, O.H. (2015). Strategies for lowering banks' cost of funds in Nigeria. CBN Working Paper Series CBN/WPS/01/2015/05.

Kang, S. (2018). Rethinking the global anti-money laundering regulations to deter corruption. International \& Comparative Law Quarterly, 67(3), 695-720.

Kasekende, L., Bagyenda, J., \& Brownbridge, M. (2011). Basel III and the global reform of financial regulation: How should Africa respond? A bank regulator's perspective. Retrieved from http://fsbwatch.org/pdf/Basel III_2011_kasakende.pdf. Accessed 16 Oct 2018.

Kochar, A. (1997). An empirical investigation of rationing constraints in rural credit markets in India. Journal of Development Economics, Elsevier, 53(2), 339-371.

Konadu-Agyemang, K. (2001). IMF and World Bank programs in Africa: Ghana's experience, 1983-1999. Aldershot, Hampshire: Ashgate International.

Kuye, O. L., Ogundele, O. J. K., \& Otike-Obaro, A. (2013). Government bailout of financially distressed banks in Nigeria: A justifiable strategy? International Journal of Business and Social Science, 4(8), 174.

Lerner, J., \& Tufano, P. (2011). The consequences of financial innovation: A counterfactual research agenda. Annual Review of Financial Economics, 3, 41-85.

Loayza, N. V., Ranciere, R., Serven, L., \& Ventura, J. (2007). Macroeconomic volatility and welfare in developing countries: An introduction. The World Bank Economic Review, 21(3), 343-357.

Mazer, R., McKee, K., and Fiorillo, A. (2014). Applying behavioural insights in consumer protection policy. CGAP.

McCallum, J., \& Blais, A. (1987). Government, special interest groups, and economic growth. Public Choice, 54(1), 3-18.

McCormack, G. (2018). Why "doing business" with the World Bank may be bad for you. European Business Organization Law Review, 19(3). 649-676.

Melzer, B. (2011). The real costs of credit access: Evidence from the payday lending market. The Quarterly Journal of Economics, 126(1), 517-555.

Morgan, D. P., Strain, M. R., \& Seblani, I. (2012). How payday credit access affects overdrafts and other outcomes. Journal of Money, Credit and Banking, 44(2-3), 519-531.

Morse, A. (2011). Payday lenders: Heroes or villains? Journal of Financial Economics, 102(1), $28-44$.

Muir-Watt, H. (2011). Private international law as global governance: Beyond the schize, from closet to planet. Transnational Legal Theory, 2(3), 347-428.

Muir-Watt, H. (2015). The relevance of private international law to the global governance debate. In H. MuirWatt \& D. P. F. Arroyo (Eds.), Private international law and global governance (pp. 1-22). Oxford: Oxford University Press.

Mylenko, N. (2008). Developing credit reporting in Nigeria: Opportunities and challenges. International Finance Corporation.

Narain, A., Rabanal, P., \& Byskov, S. (2003). Prudential issues in less diversified economies. Working Paper WP/03/198. International Monetary Fund.

Nigerian Communications Commission. (2018). Industry statistics- subscriber/teledensity data (June 2017May 2018). Retrieved fromhttps://www.ncc.gov.ng/stakeholder/statistics-reports/industry-overview\#viewgraphs-tables. Accessed 24 Oct 2018. 
Presidential Technical Committee on Land Reform. (2013). Land reform in Nigeria: Basic facts (3rd ed.). Abuja: The Presidency, Office of the Secretary to the Government of the Federation.

OECD. (2011). G-20 high-level principles on financial consumer protection. Retrieved from https://www.oecd. org/daf/fin/financial-markets/48892010.pdf. Accessed 17 October 2019.

Onagoruwa, G. A. (2014). Legitimacy deficit of soft law institutions in cross-border bank regulation: An African perspective. Journal of International Banking Law and Regulation, 34, 258.

Oxford Business Group (2015). Expanding access: Consumer credit is increasingly important to the national economy. Retrieved fromhttp:/www.oxfordbusinessgroup.com/analysis/expanding-access-consumer-creditincreasingly-important-national-economy. Accessed 5 Oct 2018.

Popoola, T. (2018). Why Telcos, Discos must embrace Credit Bureaux Services. CRC Credit Bureau Ltd. Retrieved from https:/crccreditbureau.com/media/why-telcos-disccos-must-embrace-credit-bureauxservices. Accessed 26 Apr 2019.

Ramsay, I. (2012). Consumer law and policy: Text and materials on regulating consumer markets. Oxford: Hart.

Research Republic. (2016). Improving international access to credit markets. London: City of London Corporation.

Rona-Tas, A. (2016). The role of credit bureaus in globalised economies: Why they matter less than we think and how they can matter more. In H. W. Micklitz \& I. M. Domurath (Eds.), Consumer debt and social exclusion in Europe. London: Routledge.

Rona-Tas, A., \& Guseva, A. (2018). Consumer credit in comparative perspective. Annual Review of Sociology, $44,55-75$.

Saigal, K. (2019). Regulators give mobile money in Nigeria a boost. Euromoney. Retrieved from https://www. euromoney.com/article/b1 cmtgtzyrglb9/regulators-give-mobile-money-in-nigeria-a-boost?copyrightInfo= true . Accessed 26 Apr 2019.

Santos, A. (2012). Carving out policy autonomy for developing countries in the World Trade Organization: The experience of Brazil and Mexico. Virginia Journal of International Law, 52(3), 551-632.

Sanusi, S. L. (2010). Global financial meltdown and the reforms in the Nigerian banking sector. Speech by the Governor of the Central Bank of Nigeria at a Public Lecture, delivered at Convocation Square, Abubakar Tafawa Balewa University, Bauchi, Nigeria.

Sanusi, S.L. (2012). Banking reform and its impact on the Nigerian economy. Warwick: University of Warwick's Economic Summit. Retrieved fromhttp:/www.bis.org/review/r120320d.pdf. Accessed 8 Feb 2017.

Shaffer, G., Nedumprara, J., \& Sinha, A. (2015). State transformation and the role of lawyers: The WTO, India, and transnational legal ordering. Law \& Society Review, 49(3), 595-629.

Sinha, A., Kumar, R., \& Dhal, S. C. (2011). Financial sector regulation and implications for growth (BIS Papers No. 62). Retrieved from https://www.bis.org/publ/bppdf/bispap62g.pdf . Accessed 31 Jan0 2018.

Skiba, P. M., \& Tobacman, J. (2008). Payday loans, uncertainty and discounting: Explaining patterns of borrowing, repayment, and default. Vanderbilt Law and Economics Research Paper No. 08-33.

Slovik, P., \& Cournède, B. (2011). Macroeconomic impact of Basel III (Working Paper No 844, OECD, Economics Department). COFER database, IMF.

Soederberg, S. (2014). Debtfare states and the poverty industry: Money, discipline and the surplus population. London: Routledge.

Stern, A. (2016). Moving towards a universal basic income. World Banks Job and Development Blog. Retrieved from http://blogs.worldbank.org/jobs/moving-towards-universal-basic-income . Accessed on 31 Jan 2018.

Stiglitz, J. E., \& Weiss, A. (1981). Credit rationing in markets with imperfect information. The American Economic Review, 71(3), 393-410.

This Day Life (2016). CAR: CBN extends deadline for systemically important banks. This Day Life. Retrieved from http:/www.thisdaylive.com/articles/car-cbn-extends-deadline-for-systemically-importantbanks/204924/. Accessed 8 October 2018.

Udry, C. (1990). Credit Markets in Northern Nigeria: Credit as Insurance in a Rural Economy. The World Bank Economic Review, 4(1), 251-269.

Underhill, G. R. D., \& Zhang, X. (2006). Norms, legitimacy and global financial governance. World Economy and Finance Research Programme Working Papers Series, 8, 49.

United Nations. (2016). United Nations Guidance on Consumer Protection. New York: NY.

US Department of the Treasury. (2009). Financial regulatory reform: A new foundation. Retrieved from http://www.treasury.gov/initiatives/Documents/FinalReport_web.pdf . Accessed 5 Oct 2018.

Wallace, P. (2015). Nigeria's AMCON Recovers $57 \%$ of bad debts bought in crisis. Retrieved from http://www. bloomberg.com/news/articles/2015-05-24/nigeria-s-amcon-recovers-57-of-bad-debts-bought-in-bank-crisis . Accessed 8 Oct 2018.

Wilson, T. (2008). Responsible lending or restrictive lending practices? Balancing concerns with addressing financial exclusion. In M. Kelly-Louw, J. P. Nehf, \& P. Rott (Eds.), The future of consumer credit regulation: Creative approaches to emerging problems (pp. 91-106). Aldershot: Ashgate Publishing Limited. 
Woods, N. (2006). The globalizers: The IMF, the World Bank, and their borrowers. New York, NY: Cornell University Press.

World Bank. (1989). World Development Report. Oxford: Oxford University Press.

World Bank. (2017). Good practices for financial consumer protection. Washington DC: World Bank.

Yuan, Y., \& Xu, L. (2015). Are poor able to access the informal credit market? Evidence from rural households in China. China Economic Review, 33, 232-246.

Zinman, J. (2014). Consumer credit: Too much or too little (or just right)? The Journal of Legal Studies, 43(2), S209-S237.

Publisher's Note Springer Nature remains neutral with regard to jurisdictional claims in published maps and institutional affiliations. 